\title{
Waterfowl Populations in Eastern Lancaster Sound and Western Baffin Bay
}

\author{
PETER L. McLAREN ${ }^{1}$ and MARGARET A. McLAREN ${ }^{1}$
}

\begin{abstract}
The seasonal distributions of oldsquaws (Clangula hyemalis), common eiders (Somateria mollissima) and king eiders (S. spectabilis) were determined through aerial surveys in eastern Lancaster Sound $(1976,1978,1979)$ and northwest Baffin Bay (1978, 1979). Sightings of geese are summarized in an Appendix. The major spring influx of both eiders occurs about the second week of May but most oldsquaws do not arrive until the first half of June. In spring, all three species are rare in offshore areas, are most abundant along coasts in the northern half of the study area, and tend to depart to nesting areas during the last week of June. Oldsquaws molt along coasts of Lancaster Sound and northwest Baffin Bay, but both species of eiders undertake molt migrations. Three waves of eider out-migration were detected in 1976 and 1978. Distribution and movements within the study area are related to probable migration routes and ice conditions.

Key words: oldsquaw, king eider, common eider, geese, aerial surveys, distribution, molt migration, eastern Arctic, Baffin Bay, Lancaster Sound

RÉSUMÉ. La distribution saisonnière des canards kakawis (Clangula hyemalis), des eiders communs (Somateria mollissima) et des eiders remarquable (S. spectabilis) fut déterminée à partir des relevés aériens effectués dans la partie est du détroit de Lancaster (1976, 1978, 1979) et dans la partie nord-ouest de la baie de Baffin $(1978,1979)$. L'observation des oies est résumé en appendice. La principale affluence printanière des deux espèces d'eiders se passe vers la deuxième semaine de mai; la majorité des canards kakawis, cependant, n'arrive qu'au cours de la première moitié de juin. Lors du printemps, ces trois espèces, qui se trouvent rarement au large, sont très abondantes le long des côtes situées dans la moitié nord de la région à l'étude. Ces mêmes espèces ont aussi tendance à quitter cette region pour leurs zones de nids au cours de la dernière semaine de juin. Tandis que les canards kakawis muent le long des côtes du détroit de Lancaster et de la partie nord-ouest de la baie de Baffin par contre, les deux espèces d'eiders entreprennent les migrations pour muer. Lors de 1976 et 1978, trois groupes de migration d'eiders vers l'extérieur furent observés. La distribution et les mouvements à l'intérieur de la région à l'étude sont liés aux routes de migrations possibles et à la condition des glaces.
\end{abstract}

Traduit par Ian Badgley, Aménatech inc., Sherbrooke.

\section{INTRODUCTION}

Oldsquaws (Clangula hyemalis) and king eiders (Somateria spectabilis) nest in suitable lowland habitat throughout the eastern Canadian Arctic. Common eiders (S. mollissima) occur in large numbers in spring west to at least Bathurst Island (M. McLaren, pers. obs.) but nest only along coastlines eastward from eastern Cornwallis Island (Godfrey, 1966). In the High Arctic common eiders are considerably less abundant than king eiders (Bellrose, 1976; M. McLaren, pers. obs.). The first individuals of the two eider species arrive in northwest Baffin Bay and Lancaster Sound in April (Hørring, 1937; Nelson in Gunn, 1949); the first oldsquaws do not arrive until May (Ellis, 1956; Tuck and Lemieux, 1959). During mid- and late summer there is considerable segregation of various age and sex classes of the three species. Brood-rearing females frequently remain inland whereas females without broods as well as males move to molting areas. Movements to molting areas may be either local or long-distance and many individuals, especially among the eiders, leave the study area entirely before molting (Pälmer, 1976).

We conducted aerial surveys of birds in the eastern Canadian Arctic from May to October in 1976, 1978 and 1979. The results of these surveys provide much new information about the distribution and movements of these three species from the time of their arrival in the spring until their departure in the late summer and early fall.

During our aerial surveys, Canada geese (Branta canadensis), brant (B. bernicla) and snow geese (Chen caerulescens) were also recorded. Their distributions, based on the results of the surveys, are described in an Appendix. Red-breasted mergansers (Mergus serrator) were not seen during surveys but were nonetheless present in the area. Their status has been discussed in Renaud et al. (1981).

\section{METHODS}

In 1976, weekly surveys of marine birds and mammals were conducted in eastern Lancaster Sound from 2 May-28 September. In 1978 and 1979, surveys were conducted in much of eastern Lancaster Sound and northwest Baffin Bay, usually at 1-2 wk intervals. Surveys were conducted from 4 May-10 October 1978, and from 9 May-15 July 1979. In general, each survey included flights along most or all edges of landfast ice and ice-free coastlines in the study area, and over sample areas of pack ice and open water seaward of the coasts and ice edges. Because $<1 \%$ of the observations of each waterfowl species were in offshore areas, Figure 1 shows only the survey routes along coasts and ice edges. Offshore areas surveyed are given in McLaren (1982) and Renaud and McLaren (1982). McLaren (1982) also gives the distance surveyed in each year for each section of the study area.

Surveys were flown in a deHavilland Twin Otter aircraft with observers in the copilot's seat and a left rear seat behind the pilot. Surveys were flown at $45-50 \mathrm{~m}$ above sea level at a ground speed of $160-185 \mathrm{~km} / \mathrm{h}$. Transect width was $400 \mathrm{~m}$ ( $200 \mathrm{~m}$ on either side of the aircraft), but birds seen off-transect were also recorded separately. A GNS-500 


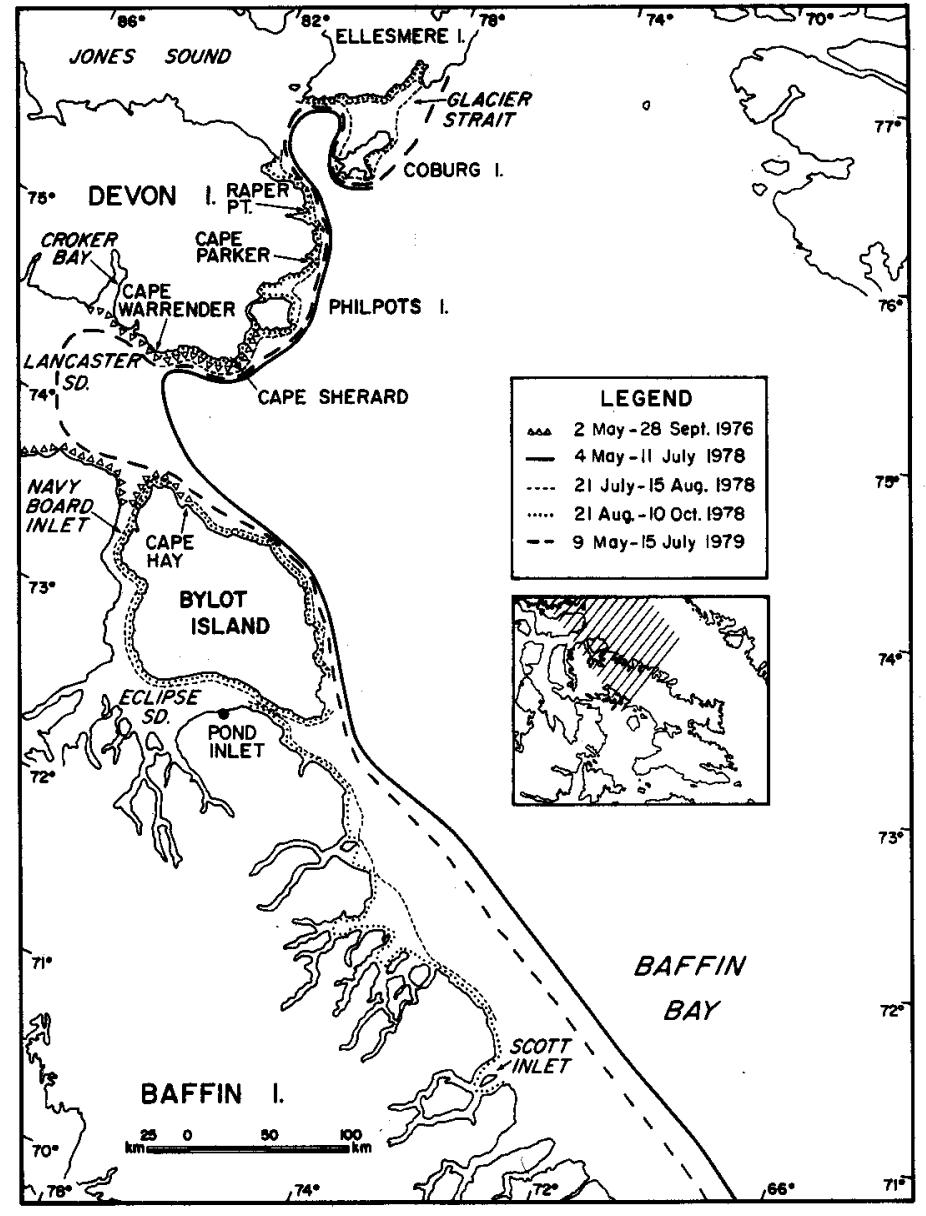

FIG. 1. Routes of coastal and ice edge surveys in eastern Lancaster Sound and western Baffin Bay, 1976, 1978 and 1979.

Global Navigation System was used in 1978-79 and a GNS-200 in 1976. Observations were dictated into tape recorders. A detailed description of the survey procedures used is presented in McLaren (1982).

The limitations and biases inherent in aerial surveys are described in McLaren (1982). A major problem of the aerial surveys specific to waterfowl was the inability of surveyors to distinguish between female common and king eiders. In spring (May-July), many flocks consisted of paired birds and the females were assumed to be the species of the male that they accompanied. Later in the season, however, after the males had departed, eiders usually could not be identified to species. Thus most summer and autumn observations were classified simply as eiders. That waterfowl are molting cannot be confirmed during aerial surveys. In this study all birds that dived or ran along the water rather than flushing as the airplane passed over were considered to be molting.

RESULTS

\section{Oldsquaw}

The earliest observation of oldsquaws during the study was 10 May (1976). In all three years, numbers present along coasts in the study area increased during May to a peak in mid- or late June. In 1976, the highest density was recorded on 20-21 June (Table 1) although numbers seen were larger on 27-28 June when a flock of 4000 was seen far off the transect strip. In 1978, peak numbers ( 4100 counted) and densities were recorded on 19-23 June (Fig. 2); in 1979 the peak was on 10-11 June (5200 counted) although numbers and densities remained high through 19-23 June (Fig. 2). In all three years densities decreased markedly after 23 June, presumably as many oldsquaws moved inland to nesting areas.

The distribution of oldsquaws during May and June differed among the three years of survey. In 1976, densities were consistently higher along the south side of Lancaster Sound than along the north side (Fig. 2C vs. 2D). In 1978, densities were low in Lancaster Sound but high in the Jones Sound-Coburg Island area and along eastern Devon Island. In 1979, oldsquaws were again common in

TABLE 1. Densities of oldsquaws along coasts and offshore ice-edges of eastern Lancaster Sound and northwest Baffin Bay in spring and early summer, 1976-1979

\begin{tabular}{|c|c|c|c|c|c|c|}
\hline \multirow{3}{*}{ Area } & \multirow[b]{2}{*}{1978} & \multicolumn{5}{|c|}{ Birds km ${ }^{-2}$} \\
\hline & & 2-24 May & $\begin{array}{l}29 \text { May- } \\
16 \text { Jun }\end{array}$ & 19-23 Jun & $\begin{array}{l}24 \text { Jun- } \\
8 \text { Jul }\end{array}$ & 10-26 Jul \\
\hline & 1979 & 9-26 May & 1-11 Jun & 19-23 Jun & $\begin{array}{l}28 \text { Jun- } \\
2 \text { Jul }\end{array}$ & 9-15 Jul \\
\hline \multicolumn{7}{|l|}{ Islands } \\
\hline \multirow[t]{2}{*}{ Coburg } & 1978 & 0.1 & 18.5 & 30.6 & 0.7 & 0.0 \\
\hline & 1979 & 0.0 & 3.4 & 11.3 & 0.0 & 0.2 \\
\hline \multirow[t]{2}{*}{ NE Devon } & 1978 & 0.1 & 0.8 & 6.1 & 0.7 & $<0.1$ \\
\hline & 1979 & 0.0 & 1.0 & 0.6 & 0.1 & 0.0 \\
\hline \multirow[t]{2}{*}{ E Devon } & 1978 & 0.0 & 0.7 & 10.1 & 3.2 & 0.7 \\
\hline & 1979 & 0.0 & 3.3 & 5.3 & 1.0 & 0.7 \\
\hline \multirow[t]{3}{*}{ SE Devon } & $1976^{a}$ & $<0.1$ & 5.4 & 6.3 & 9.3 & 7.3 \\
\hline & 1978 & 0.0 & 0.7 & 25.7 & 4.6 & 4.0 \\
\hline & 1979 & 0.0 & 41.8 & 59.5 & 10.0 & 1.6 \\
\hline N Bylot/ & $1976^{a}$ & $<0.1$ & 8.6 & 63.0 & 24.0 & 2.7 \\
\hline \multirow[t]{2}{*}{ N Baffin } & 1978 & 0.1 & 1.2 & 0.9 & 1.1 & 0.2 \\
\hline & 1979 & 0.0 & 29.7 & 1.2 & 1.5 & 0.2 \\
\hline \multirow[t]{2}{*}{ E Bylot } & 1978 & 0.0 & 0.9 & 1.0 & 1.2 & 0.7 \\
\hline & 1979 & 0.0 & 0.8 & 6.7 & 2.1 & 1.5 \\
\hline \multirow[t]{2}{*}{ E Baffin } & 1978 & 0.0 & 0.8 & 1.4 & 0.8 & 0.1 \\
\hline & 1979 & 0.1 & 0.6 & 1.1 & 0.7 & $<0.1$ \\
\hline \multicolumn{7}{|c|}{ Offshore Ice Edges } \\
\hline \multirow[t]{2}{*}{ Glacier Str. } & 1978 & 0.0 & 2.2 & 6.9 & 0.7 & 0.1 \\
\hline & 1979 & 0.0 & 0.5 & 0.0 & $<0.1$ & 0.0 \\
\hline \multirow[t]{2}{*}{ Jones Sound } & 1978 & $<0.1$ & 1.6 & 46.3 & 3.0 & 0.3 \\
\hline & 1979 & 0.0 & 0.2 & 0.8 & 0.0 & 0.0 \\
\hline \multicolumn{7}{|l|}{ Lancaster } \\
\hline \multirow[t]{2}{*}{ Sound } & 1978 & 0.0 & 0.3 & 0.1 & 0.2 & 0.1 \\
\hline & 1979 & 0.0 & 0.4 & 5.0 & 0.1 & 0.0 \\
\hline \multirow[t]{2}{*}{ Pond Inlet } & 1978 & 0.0 & 0.0 & 0.8 & 0.1 & 0.0 \\
\hline & 1979 & 0.0 & 0.6 & 0.4 & 0.0 & 0.3 \\
\hline \multirow{2}{*}{$\begin{array}{l}\text { Navy Board } \\
\text { Inlet }\end{array}$} & $1976^{\mathrm{a}}$ & 0.0 & $<0.1$ & 0.6 & 4.3 & 0.0 \\
\hline & 1979 & 0.0 & 0.8 & 0.0 & 0.8 & 0.0 \\
\hline \multirow{3}{*}{ Overall } & $1976^{\mathrm{a}}$ & $<0.1$ & 7.0 & 34.6 & 16.6 & 5.0 \\
\hline & 1978 & $<0.1$ & 1.2 & 9.1 & 1.5 & 0.4 \\
\hline & 1979 & $<0.1$ & 6.3 & 6.0 & 1.3 & 0.5 \\
\hline
\end{tabular}

a Date ranges for 1976 are within those given for 1978. 

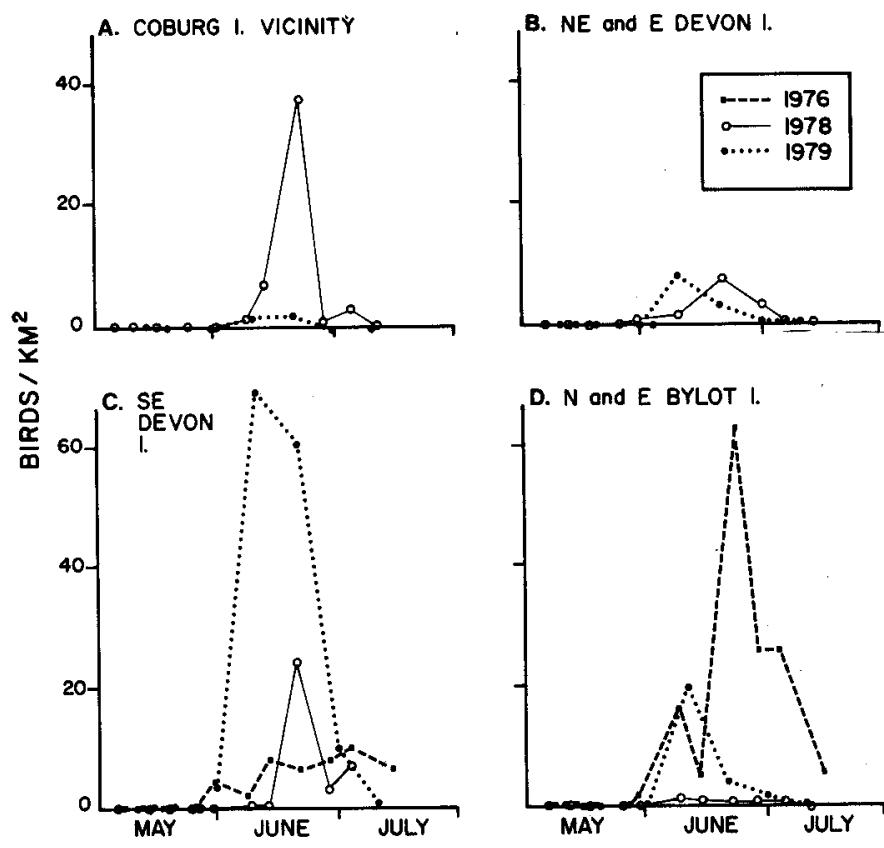

FIG. 2. Mean densities of oldsquaws in selected coastal areas of eastern Lancaster Sound and western Baffin Bay, May-July 1976, 1978 and 1979.

TABLE 2. Major molting areas and numbers of molting oldsquaws and eiders

\begin{tabular}{|c|c|c|c|c|c|c|c|c|}
\hline & & \multirow[b]{2}{*}{ Area $^{a}$} & \multicolumn{3}{|c|}{ Oldsquaw } & \multicolumn{3}{|c|}{ Eiders } \\
\hline & & & Surveys $^{b}$ & $\begin{array}{l}\text { Mean } \\
\text { count }\end{array}$ & $\begin{array}{l}\text { Peak } \\
\text { count }\end{array}$ & Surveys ${ }^{b}$ & $\begin{array}{l}\text { Mean } \\
\text { count }\end{array}$ & $\begin{array}{l}\text { Peak } \\
\text { count }\end{array}$ \\
\hline \multirow[t]{2}{*}{ Ellesmere I. } & 1978 & 1 & 1 & 30 & 30 & 4 & 65 & 175 \\
\hline & 1978 & 2 & 0 & 0 & 0 & 1 & 2 & 2 \\
\hline \multirow[t]{8}{*}{ Devon I. } & 1978 & 3 & 3 & 52 & 71 & 0 & 0 & 0 \\
\hline & 1978 & 4 & 2 & 35 & 50 & 0 & 0 & 0 \\
\hline & 1978 & 5 & 3 & 225 & 370 & 1 & 3 & 3 \\
\hline & 1976 & 6 & 1 & 75 & 75 & 2 & 24 & 25 \\
\hline & 1978 & 6 & 4 & 273 & 500 & $\mathbf{0}$ & 0 & 0 \\
\hline & 1976 & 7 & 5 & 172 & 350 & 7 & 306 & 820 \\
\hline & 1978 & 7 & 3 & 355 & 461 & 1 & 55 & 55 \\
\hline & 1976 & 8 & 1 & 100 & 100 & 0 & 0 & 0 \\
\hline \multirow[t]{9}{*}{ Bylot I. } & 1978 & 9 & 2 & 90 & 150 & 0 & 0 & 0 \\
\hline & 1978 & 10 & 2 & 260 & 405 & 1 & 100 & 100 \\
\hline & 1978 & 11 & 1 & 25 & 25 & 0 & 0 & 0 \\
\hline & 1978 & 12 & 0 & 0 & 0 & 1 & 35 & 35 \\
\hline & 1978 & 13 & 1 & 255 & 255 & 2 & 50 & 75 \\
\hline & 1978 & 14 & 4 & 839 & 2520 & 0 & 0 & 0 \\
\hline & 1978 & 15 & 2 & 34 & 50 & 1 & 250 & 250 \\
\hline & 1978 & 16 & 0 & 0 & 0 & 1 & 400 & 400 \\
\hline & 1978 & 17 & 8 & 1150 & 2754 & 1 & 355 & 355 \\
\hline \multirow[t]{8}{*}{ Baffin I. } & 1978 & 18 & 2 & 400 & 430 & 2 & 105 & 200 \\
\hline & 1978 & 19 & 0 & 0 & 0 & 2 & 241 & 349 \\
\hline & 1978 & 20 & 4 & 989 & 2640 & 0 & 0 & 0 \\
\hline & 1978 & 21 & 2 & 850 & 1500 & 0 & 0 & 0 \\
\hline & 1978 & 22 & 0 & 0 & 0 & 1 & 20 & 20 \\
\hline & 1978 & 23 & 0 & 0 & $\mathbf{0}$ & 1 & 100 & 100 \\
\hline & 1978 & 24 & 1 & 70 & 70 & 0 & 0 & 0 \\
\hline & 1978 & 25 & 2 & 746 & 791 & 0 & 0 & 0 \\
\hline
\end{tabular}

\footnotetext{
See Figure 3.

b Number of surveys during which molting birds were recorded.
}

Lancaster Sound but, unlike 1976, densities were highest along the north side (Fig. 2; Table 1). Relatively few were seen in 1979 in the Jones Sound-Coburg Island area or along east Devon Island. In 1978 and 1979 only the occasional flock was seen along eastern Bylot and Baffin islands

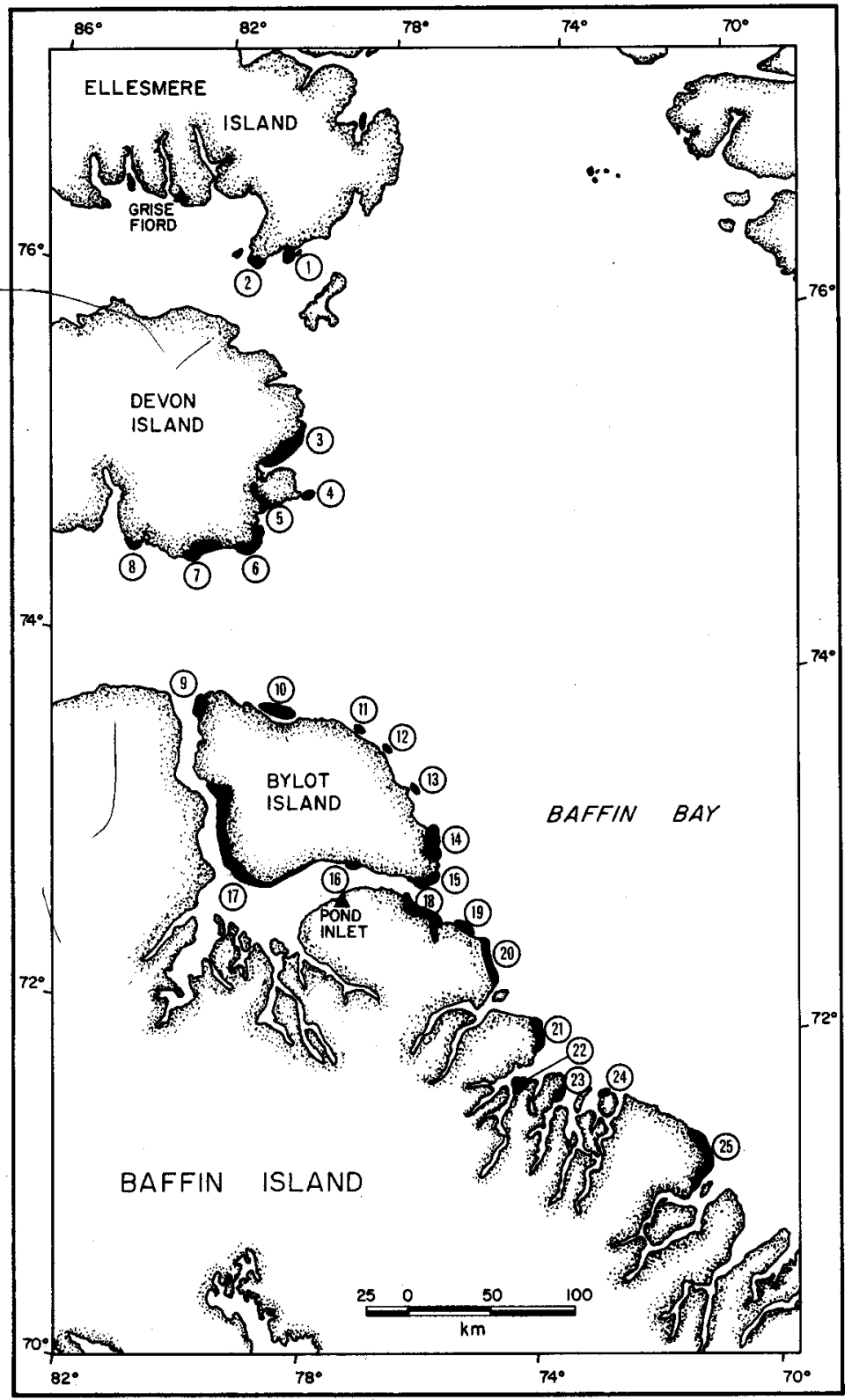

FIG. 3. Molting areas of oldsquaws and of king and common eiders. (Numbers correspond to numbers in Table 2 .)

and in all three years oldsquaws were rarely seen $>1 \mathrm{~km}$ from a coast or fast ice edge even though the majority of the survey effort was farther offshore.

Most oldsquaws seen from mid-July to mid-September were molting birds. Molters were first seen on 7 July in 1976 and on 30 July in 1978. In 1976, when only Lancaster Sound was surveyed, all molters seen were along southern Devon Island (Fig. 3; Table 2). In 1978, the southwest coast of Bylot Island (not surveyed in 1976) was the most heavily and consistently used molting area. Molters were seen there regularly from 30 July-27 September, with a peak count of 2754 on 28 August. Other important molting areas included parts of the east coasts of Devon, Bylot and Baffin islands (Fig. 3). In 1979, surveys were not conducted after mid-July. 
TABLE 3. Densities (birds km $\mathrm{km}^{-2}$ ) of eiders along coasts and ice-edges of northwest Baffin Bay and Lancaster Sound in spring and early summer, 1976-1979

\begin{tabular}{|c|c|c|c|c|c|c|c|c|c|c|c|c|c|}
\hline \multirow{2}{*}{ Area } & & \multicolumn{3}{|c|}{ 2-7 May } & \multicolumn{3}{|c|}{ 8-15 May } & \multicolumn{3}{|c|}{ 15-26 May } & \multicolumn{3}{|c|}{29 May - 23 June } \\
\hline & & $\mathrm{KE}^{\mathrm{a}}$ & $C E^{a}$ & $A E^{a}$ & $\mathrm{KE}$ & CE & $\mathrm{AE}$ & $\mathrm{KE}$ & $\mathrm{CE}$ & $\mathrm{AE}$ & $\mathrm{KE}$ & CE & AE \\
\hline \multirow{4}{*}{$\begin{array}{l}\text { Glacier Strait } \\
\text { ice-edge } \\
\text { Coburg I. }\end{array}$} & 1978 & 151.9 & 0.0 & 167.4 & 12.4 & 1.8 & 83.0 & 30.8 & 8.5 & 374.2 & 13.9 & 9.4 & 68.3 \\
\hline & 1979 & $-b$ & - & - & 49.8 & 3.4 & 53.1 & 20.1 & 0.1 & 54.5 & 5.9 & 1.1 & 16.8 \\
\hline & 1978 & 343.4 & 0.0 & 343.4 & 186.7 & 5.2 & 517.4 & 30.9 & 24.9 & 107.8 & 0.7 & 5.5 & 57.3 \\
\hline & 1979 & - & - & - & 720.9 & 30.9 & 780.6 & 444.7 & 18.7 & 660.6 & 38.2 & 19.3 & 90.8 \\
\hline \multirow{4}{*}{$\begin{array}{l}\text { Jones Sound } \\
\text { ice-edge } \\
\text { NE Devon I. }\end{array}$} & 1978 & 0.4 & 0.0 & 0.4 & 24.0 & 1.3 & 43.4 & 28.3 & 8.2 & 44.4 & 6.7 & 6.3 & 1176 \\
\hline & 1979 & - & - & - & 234.0 & 2.1 & 236.1 & 2.0 & 0.0 & 4.8 & 0.8 & 1.4 & 4.3 \\
\hline & 1978 & 0.0 & 0.0 & 8.1 & 26.2 & 3.0 & 29.1 & 57.6 & 17.5 & 100.5 & 12.0 & 12.7 & 106.6 \\
\hline & 1979 & - & - & - & 0.0 & 0.1 & 0.1 & 0.0 & 0.0 & 1.5 & 4.0 & 6.1 & 18.5 \\
\hline \multirow[t]{2}{*}{ E Devon I. } & 1978 & 7.8 & 0.0 & 7.8 & 2.0 & 0.0 & 2.0 & 77.3 & 33.4 & 136.7 & 17.4 & 13.3 & 209.0 \\
\hline & 1979 & - & - & - & 24.2 & 7.3 & 32.0 & 37.4 & 17.4 & 91.0 & 13.4 & 55.1 & 96.0 \\
\hline \multirow[t]{3}{*}{ SE Devon I. } & 1976 & 1.0 & 0.1 & 1.5 & 3.0 & 0.0 & 3.1 & 47.2 & 10.0 & 57.4 & 13.6 & 8.0 & 24.8 \\
\hline & 1978 & 12.8 & 0.0 & 12.8 & 0.0 & 0.0 & 7.5 & 31.7 & 0.3 & 161.5 & 17.4 & 7.6 & 236.1 \\
\hline & 1979 & - & - & - & 6.5 & $<0.1$ & 7.0 & 1.8 & 3.7 & 8.8 & 142.6 & 54.3 & 287.4 \\
\hline \multicolumn{14}{|l|}{ Lancaster } \\
\hline Sound & 1978 & 2.4 & 0.0 & 0.0 & 11.3 & 0.1 & 15.6 & 0.1 & 0.3 & 1.6 & 4.7 & 1.2 & 7.9 \\
\hline ice-edge & 1979 & - & - & - & 0.0 & 0.0 & $<0.1$ & 0.0 & 0.0 & 0.0 & 6.9 & 2.9 & 11.2 \\
\hline N Baffin/ & 1976 & 13.6 & 0.2 & 13.8 & 4.3 & 0.0 & 4.3 & 22.3 & 0.0 & 22.3 & 20.5 & 5.5 & 30.8 \\
\hline \multirow[t]{2}{*}{ N Bylot I. } & 1978 & 0.0 & 0.0 & 0.0 & 1.9 & 0.0 & 1.9 & 3.4 & $<0.1$ & 9.1 & 3.2 & 1.4 & 8.4 \\
\hline & 1979 & - & - & - & 60.7 & 0.1 & 79.0 & 15.2 & 0.1 & 44.0 & 9.8 & 5.2 & 49.4 \\
\hline \multirow[t]{2}{*}{ E Bylot I. } & 1978 & 0.1 & 0.0 & 0.1 & 15.6 & 0.0 & 17.7 & 1.0 & 0.2 & 2.6 & 2.3 & 0.2 & 3.4 \\
\hline & 1979 & - & - & - & 15.2 & 0.1 & 18.6 & 18.4 & 0.0 & 20.3 & 0.4 & 0.1 & 0.6 \\
\hline \multirow{4}{*}{$\begin{array}{l}\text { Pond Inlet } \\
\text { ice-edge } \\
\text { E Baffin I. }\end{array}$} & 1978 & 0.0 & 0.0 & 0.0 & 18.0 & 0.0 & 19.2 & 2.3 & 0.2 & 9.1 & $<0.1$ & 0.0 & 1.1 \\
\hline & 1979 & - & - & - & 2.1 & 0.0 & 2.1 & 0.1 & 6.0 & 0.1 & 0.6 & 0.3 & 0.9 \\
\hline & 1978 & $<0.1$ & 0.0 & $<0.1$ & 29.1 & 0.1 & 29.2 & 0.6 & $<0.1$ & .0 & 1.3 & 0.3 & 3.8 \\
\hline & 1979 & - & - & - & 0.0 & 0.0 & 0.0 & 3.7 & 0.6 & 5.7 & 1.2 & 0.5 & 2.3 \\
\hline \multirow{3}{*}{ OVERALL } & 1976 & 7.6 & 0.2 & 8.0 & 3.7 & 0.0 & 3.7 & 35.4 & 5.2 & 40.7 & 16.7 & 6.9 & 28.3 \\
\hline & 1978 & 17.2 & 0.0 & 18.0 & 25.1 & 0.6 & 43.9 & 19.8 & 6.6 & 56.9 & 6.0 & 3.8 & 59.4 \\
\hline & 1979 & - & - & - & 46.2 & 1.6 & 51.1 & 19.2 & 1.9 & 35.0 & 15.6 & 10.4 & 41.7 \\
\hline
\end{tabular}

${ }^{\mathrm{a}} \mathrm{KE}=$ king eider, $\mathrm{CE}=$ common eider, $\mathrm{AE}=$ all eiders.

b A dash indicates 'not surveyed'.

In 1976, oldsquaw densities increased in Lancaster Sound after mid-September; this probably reflected arrival of migrating birds from the west. Over $\mathbf{4 0 0 0}$ oldsquaws were seen during the last survey on 26-28 September. Densities in 1978 decreased from 7.1 birds $\mathrm{km}^{-2}$ on $18-22$ September to $1.2 \mathrm{~km}^{-2}$ on 30 September-4 October. Only 30 oldsquaws $\left(0.1 \mathrm{~km}^{-2}\right)$ were seen during the final survey on $7-10$ October.

\section{Eiders}

Eiders were common in parts of the study area by early May (Fig. 4). Virtually all seen at this time were king eiders. Most were in flocks of pairs and they were especially numerous along the south side of Coburg Island (Table 3). Common eiders returned about mid-May and they too were most numerous near Coburg Island. Numbers of both species increased throughout May, with a notable movement of king eiders along the landfast ice edge bordering east Baffin Island (Table 3). These birds apparently continued north beyond Baffin Island. By late May, both king and common eiders were common along most coastlines north of Pond Inlet (Table 3), but few remained along the ice edge off east Baffin Island. Eiders were rare in offshore areas of Lancaster Sound and Baffin Bay at all times.

In late May and early June of 1978 and 1979, eider densities near Coburg Island decreased sharply. This decrease occurred about the same time that large numbers began to occur along the shorelines of Lancaster Sound, especially along southeast Devon Island. In 1976, 1978 and 1979 peak numbers were recorded in Lancaster Sound during early June (Fig. 5). Both common and king eiders were represented in this buildup. Far fewer were seen in 1978 than in 1976 or 1979.

Eiders were common during most of June. Distribution, however, varied somewhat among the three years, probably in response to ice conditions. In 1978, large flocks were seen regularly at ice-free headlands along northeast Devon Island; in 1979, these headlands were not clear of ice until late June and instead eiders concentrated along the icefree east coast of Devon Island between Raper Point and Cape Parker. Although densities were high along southeast Devon Island in 1978 (Table 3), most eiders were in a 

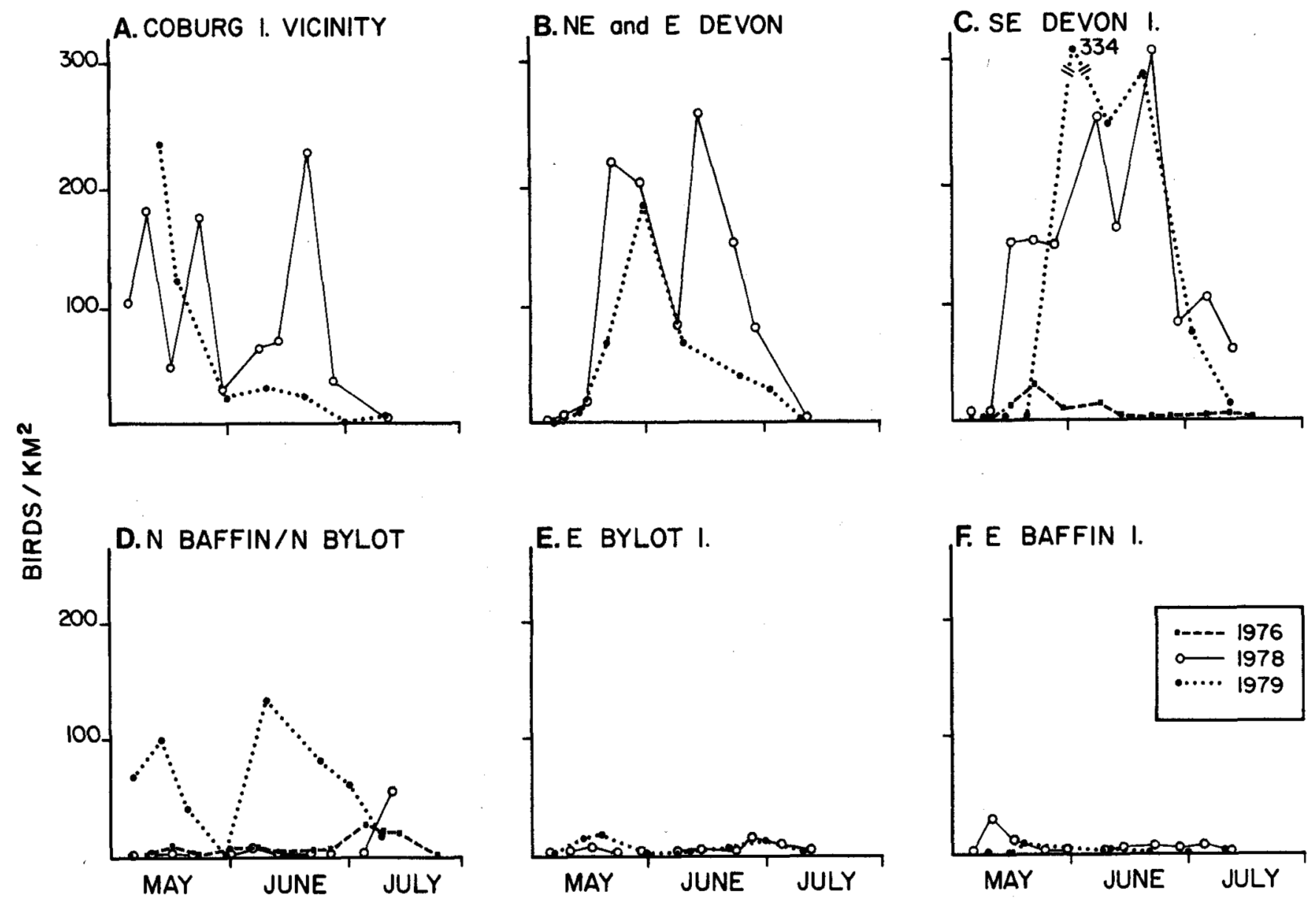

FIG. 4. Mean densities of eiders (Somateria spp.) in selected coastal areas of eastern Lancaster Sound and western Baffin Bay, May-July 1976, 1978 and 1979.

few large flocks at Cape Sherard and south of Philpots Island, rather than being widely distributed along the south coast as in 1979. In 1978, over 17000 eiders were present in the Coburg Island-southeast Ellesmere Island area on 20 June; no large concentrations were present there in 1979.

In late June, densities of eiders had become much lower along all coasts in the study area, presumably because individuals moved to terrestrial nesting areas both within and outside the study area.

During July and August, numbers of eiders increased again along coasts as a series of migratory movements occurred. The major route out of the study area was through Lancaster Sound where densities were considerably higher than in other parts of the study area (Table 4). King eider males were the first to begin moving out of the study area. The sex ratio (of birds whose sex was recorded) of king eiders was $\sim 1: 1$ during 1-10 July in both 1976 and 1978 . Thereafter, the proportion of males gradually increased until, during 21 July-3 August, almost all king eiders identified were males (Table 5). (Since female eiders were never identified unless they were with males, the increasing proportion of males implies an increase in post-nesting migratory flocks of males.) Peak numbers of male king eiders were recorded about a week earlier in 1976 than in 1978 (Table 5), although in both years peak densities were much higher along northern Baffin Island and northern and eastern Bylot Island than along southern Devon Island (9.7 vs. 0.2 birds km$~^{-2}$ in $1976,25.3$ vs. 0.3 birds km in 1978). After the first few days of August few king eiders were identified anywhere in the study area.

In 1976, numbers of common eiders identified during surveys from 4-19 July changed little and the sex ratio of those sexed was $\sim 1: 1$. On $25-26$ July numbers seen remained similar but $71 \%$ were males (Table 5). Over 300 common eiders observed on 25-26 July were migrating east over Lancaster Sound and $80 \%$ of these were males. After 26 July numbers of common eiders decreased rapidly and very few were identified after 15 August. In 1978 no distinct migration of common eiders was detected. Rather, the numbers and sex ratio of common eiders remained similar through July and early August. After 15 August no common eider males were identified until late September when a few were seen.

An influx of unidentified female eiders occurred in midAugust, primarily in Lancaster Sound and along eastern 


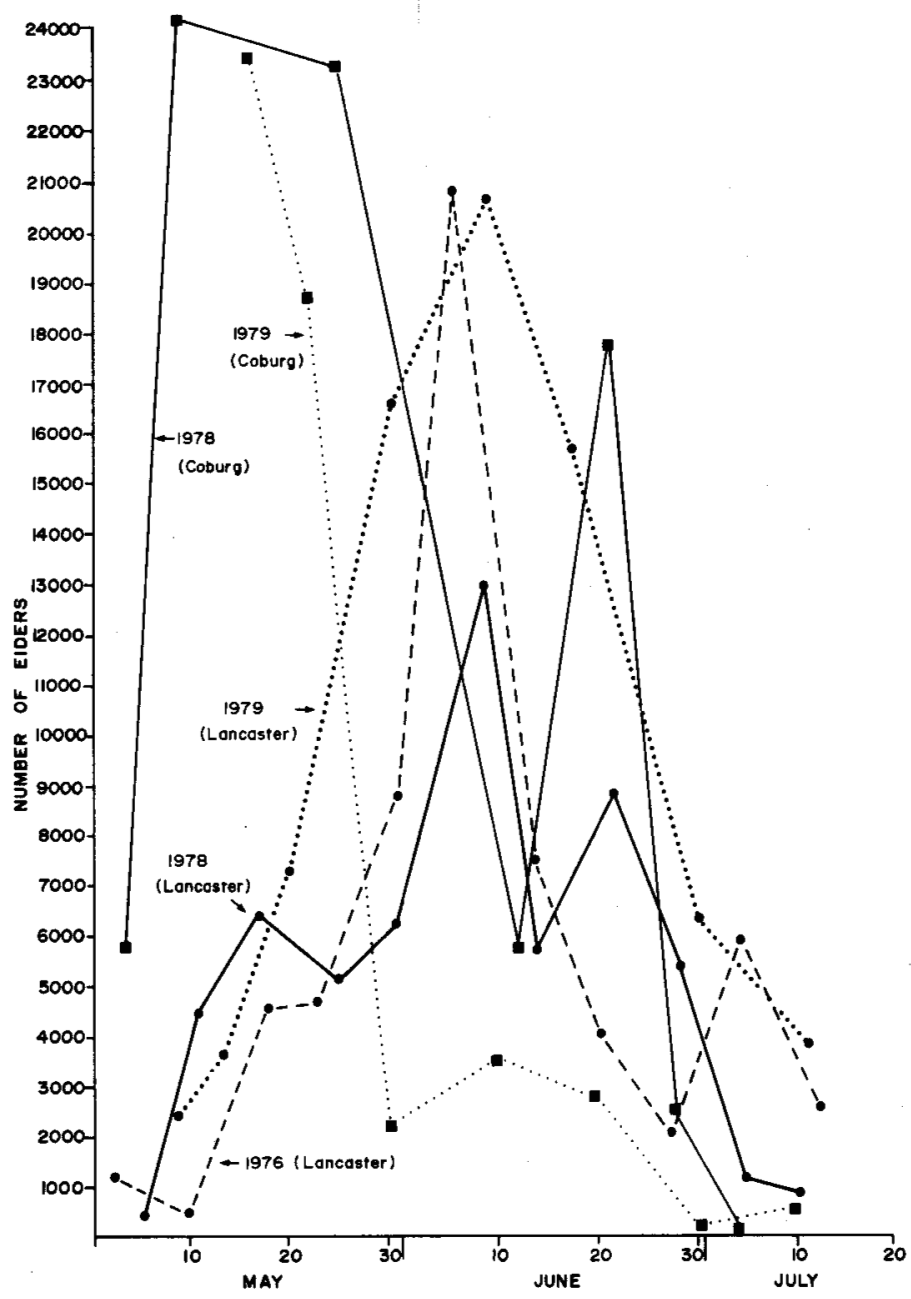

FIG. 5. Number of eiders observed during aerial surveys in the Coburg Island area and in eastern Lancaster Sound, May-July 1976, 1978, and 1979.
Bylot Island. In 1976, numbers recorded increased from 1369 during the 31 July-3 August survey to 10004 on 8-10 August. During the survey on 16-17 August only 2368 eiders were counted. In 1978, peak numbers (25 127 birds) were recorded during a survey on 11-15 August. Numbers recorded during the previous and subsequent surveys were about half the peak number. Peak numbers of females were recorded along the north and east coasts of Bylot Island: $\sim 22000$ were seen on 12 August. An additional 7700 female eiders were observed flying east past Cape Hay on 17 August 1978 (W.E. Renaud, pers. comm.). Numbers and densities of female eiders declined thereafter. A substantial proportion of the eiders remaining in the study area apparently departed between the 30 September- 4 October and the 7-10 October surveys. The overall density decreased from 4.7 to 1.2 birds $\mathrm{km}^{-2}$ during this period.

Relatively few eiders molted in the study area. In 1976 and 1978, respectively, 2187 eiders ( $278 \mathrm{king}, 117$ common and 1792 unidentified) and 2352 eiders ( 323 king, 10 common and 2019 unidentified) were classified as molting. In both years it is likely that individual eiders were counted more than once since molting birds were recorded in the same areas during several surveys (Table 2, Fig. 3).

Eggs of both eider species hatch primarily in early August (Hussell and Holroyd, 1974) but no eider females seen with broods were identified to species in 1976 or 1978 . Although the area surveyed was considerably smaller in 1976 than in 1978, over twice as many eider broods were recorded in 1976 (Table 6). Most of the eider broods and creches recorded in 1976 were along the south coast of Devon Island and especially between Cape Sherard and Cape Warrender. Several broods were also recorded in this area in 1978.

TABLE 4. Densities (birds $\mathrm{km}^{-2}$ ) of eiders in eastern Lancaster Sound and northwest Baffin Bay in summer and fall, 1976, 1978-1979

\begin{tabular}{|c|c|c|c|c|c|c|c|c|c|c|c|}
\hline \multirow[b]{2}{*}{ Area } & & \multicolumn{3}{|c|}{ 9-26 Jul } & \multicolumn{3}{|c|}{$28 \mathrm{Jul}-15$ Aug } & \multicolumn{3}{|c|}{ 16-25 Aug } & \multirow{2}{*}{$\frac{26 \text { Aug-10 Oct }}{\mathrm{AE}}$} \\
\hline & & $\mathbf{K E}^{\mathbf{a}}$ & $\mathrm{CE}^{\mathrm{a}}$ & $\mathrm{AE}^{\mathrm{a}}$ & $\mathrm{KE}$ & $\mathrm{CE}$ & $\mathrm{AE}$ & $\mathrm{KE}$ & CE & $\mathrm{AE}$ & \\
\hline \multirow{4}{*}{$\begin{array}{l}\text { Jones Sd. } \\
\text { area } \\
\text { E Devon I. }\end{array}$} & 1978 & 0.4 & 1.7 & 3.4 & 0.7 & 4.5 & 6.7 & 0.0 & 0.0 & 5.4 & 3.4 \\
\hline & 1979 & 0.1 & 4.7 & 6.4 & $-{ }^{b}$ & - & - & - & - & - & - \\
\hline & 1978 & 2.1 & 1.2 & 5.8 & 0.0 & 5.2 & 7.9 & 0.0 & 0.0 & 5.3 & 2.4 \\
\hline & 1979 & 5.0 & 2.3 & 7.7 & - & - & - & - & - & - & - \\
\hline Lancaster & 1976 & 4.1 & 5.4 & 16.5 & 1.6 & 2.5 & 15.8 & 0.0 & 0.3 & 11.3 & 8.1 \\
\hline \multirow{2}{*}{ Sd. area } & 1978 & 1.7 & 8.2 & 27.4 & 11.3 & 0.3 & 45.0 & 0.0 & 0.0 & 28.1 & 4.0 \\
\hline & 1979 & 3.8 & 3.5 & 23.5 & - & - & - & - & - & - & - \\
\hline S \& W & 1978 & - & - & - & 0.2 & 1.3 & 4.1 & 0.0 & 0.0 & 5.7 & 4.8 \\
\hline Bylot I. & 1979 & 0.0 & 0.0 & 0.0 & - & - & - & - & - & - & - \\
\hline E Bylot I./ & 1978 & 1.4 & $<0.1$ & 4.8 & 4.9 & 0.9 & 56.9 & 0.1 & 0.0 & 17.1 & 2.3 \\
\hline E Baffin I. & 1979 & 0.4 & 0.5 & 1.6 & - & - & - & - & - & - & - \\
\hline \multirow[t]{2}{*}{ OVERALL } & 1978 & 1.2 & 2.0 & 8.5 & 3.5 & 2.0 & 29.1 & $<0.1$ & $<0.1$ & 14.1 & 3.4 \\
\hline & 1979 & 1.4 & 2.0 & 7.8 & - & - & - & - & - & - & - \\
\hline
\end{tabular}

${ }^{a} \mathrm{KE}=$ king eider, $\mathrm{CE}=$ common eider, $\mathrm{AE}=$ all eiders.

' A dash indicates 'not surveyed'. 
TABLE 5. Proportion of males among identified eiders in eastern Lancaster Sound and northwest Baffin Bay in summer 1976, 1978-1979

\begin{tabular}{|c|c|c|c|c|c|c|c|}
\hline \multirow[b]{2}{*}{ Date } & & \multicolumn{3}{|c|}{ King eider } & \multicolumn{3}{|c|}{ Common eider } \\
\hline & & $\begin{array}{c}\text { No. } \\
\text { identified }^{\mathrm{a}}\end{array}$ & $\begin{array}{c}\% \\
\text { sexed }\end{array}$ & $\begin{array}{c}\% \\
\text { males }^{\mathrm{b}}\end{array}$ & $\begin{array}{c}\text { No. } \\
\text { identified }^{\mathrm{a}}\end{array}$ & $\begin{array}{c}\% \\
\text { sexed }\end{array}$ & $\begin{array}{c}\% \\
\text { males }^{\mathrm{b}}\end{array}$ \\
\hline \multirow[t]{2}{*}{ 3-8 Jul } & 1976 & 2371 & 30 & 41 & 1043 & 66 & 52 \\
\hline & 1978 & 958 & 24 & 53 & 696 & 27 & 57 \\
\hline \multirow[t]{3}{*}{ 9-15 Jul } & 1976 & 481 & 8 & 66 & 844 & 42 & 56 \\
\hline & 1978 & 187 & 50 & 70 & 787 & 76 & 74 \\
\hline & 1979 & 1333 & 21 & 86 & 1115 & 43 & 62 \\
\hline 18-19 Jul & 1976 & 711 & 16 & 60 & 1168 & 66 & 47 \\
\hline $21-26 \mathrm{Jul}$ & 1976 & 1048 & 72 & 96 & 1013 & 81 & 71 \\
\hline & 1978 & 821 & 52 & 87 & 621 & 40 & 68 \\
\hline 28 Jul- & 1976 & 426 & 36 & 85 & 548 & 64 & 50 \\
\hline 3 Aug & 1978 & 3017 & 30 & 96 & 912 & 85 & 54 \\
\hline 8-15Aug & 1976 & 1 & 100 & 100 & 222 & 92 & 42 \\
\hline & 1978 & 483 & 4 & 100 & 1194 & 17 & 43 \\
\hline
\end{tabular}

a Includes off-transect observations.

b Percent males among sexed individuals.

DISCUSSION

\section{Oldsquaw Distribution and Movements}

The timing of arrival of oldsquaws in the Lancaster Sound-northwest Baffin Bay area in spring, and their distribution after arrival, are probably influenced by climatic conditions in the study area and farther south. In both 1976 and 1978, few oldsquaws appeared until about 20 June and thereafter numbers remained high until the end of June. In both those years, snow remained on the ground much later than usual and temperatures at Pond Inlet were below normal. Farther south, at Frobisher Bay, June temperatures in 1978 were $3.3^{\circ} \mathrm{C}$ below normal, and in that year at least, the arrival of birds in Lancaster Sound may have been delayed by the wintry conditions farther south. In 1979, on the other hand, rate of snowmelt in the study area was average, and May temperatures at Frobisher Bay were about $3^{\circ} \mathrm{C}$ above normal. Densities of oldsquaws in the study area peaked about 10 days earlier in 1979 than in 1978, and remained high for about two weeks. Warm weather to the south likely induced the birds to move north earlier in 1979 than in 1976 or 1978, but they were then forced to wait in coastal areas until the snow cleared from terrestrial nesting areas. Hussell and Holroyd (1974) reported that oldsquaws begin to arrive at nesting areas on northern Devon Island in the third week of June.

We obtained no clear evidence of long-distance molt migrations by oldsquaws (i.e. movements from nesting areas to distant molting areas), but oldsquaws did molt in groups of tens or hundreds at various locations along coasts in the study area. In 1978 the first molting oldsquaws were observed on 30 July, considerably later than in 1976 ( 7 July). The difference may be largely a function of the different survey route in 1978 , and the very different ice conditions. All molters seen in 1976 were along south-
TABLE 6. Locations and sizes of eider broods seen in eastern Lancaster Sound and northwest Baffin Bay in 1976 and 1978

\begin{tabular}{lcrrr}
\hline \hline & & $\begin{array}{c}\text { No. of } \\
\text { broods }\end{array}$ & $\begin{array}{r}\text { No. of } \\
\text { young }\end{array}$ & $\begin{array}{r}\text { No. of } \\
\text { adults }\end{array}$ \\
\hline Ellesmere I. & 1978 & 3 & 13 & 4 \\
E Devon I. & 1978 & 10 & 76 & 23 \\
SE Devon I. & 1976 & 69 & 677 & 178 \\
& 1978 & 8 & 83 & 20 \\
NE Bylot I. & 1976 & 1 & 16 & 4 \\
W Bylot I. & 1978 & 11 & 47 & 13 \\
& 1976 & 1 & 11 & 2 \\
E Baffin I. & 1978 & 2 & 11 & 4 \\
N Baffin I. & 1978 & 2 & 6 & 2 \\
\hline Total & 1976 & 5 & 38 & 10 \\
& 1976 & 76 & 742 & 194 \\
\hline
\end{tabular}

ern Devon Island, an area covered by landfast ice until late July in 1978. Surveys of southwest Bylot Island, the most heavily used molting area in 1978 , did not commence until $30 \mathrm{July}$; it is quite possible that molting birds were in that area much earlier.

Many of the molting areas identified were in the lee of headlands, which possibly provide shelter for molting birds. Similarly, the largest concentrations of molting oldsquaws in Chesterfield Inlet, Keewatin District, in 1977 were in the lee of prominent headlands (P. McLaren, pers. obs.). Johnson and Richardson (1981) found that molting and post-molting oldsquaws in Alaska moved, with changing winds, to the more sheltered side of a lagoon.

The lengthy period (almost two months) over which molting oldsquaws were observed no doubt reflects the behaviour of different segments of the population. Males leave the nesting areas and initiate molt during July; some females desert their broods and move to molting areas after hatch in late July or early August. Other females remain with the young until fledging and then move to molting areas (Alison, 1975). Young oldsquaws remain in the natal area until fledging (Alison, 1975), which would probably occur in early September. Some of the oldsquaws seen in September and October were probably young-ofthe-year.

\section{Eider Distribution and Movements}

Large numbers of common and king eiders appear around Coburg Island in early May, which is substantially earlier than similar numbers appear elsewhere in the study area. These individuals have likely come from wintering areas along the southwest coast of Greenland, having followed the Greenland coast north to Melville Bay and thence across to Coburg Island. Both species arrive in northwest Greenland in late April (Salomonsen, 1950), and king eiders have reached $81^{\circ} \mathrm{N}$ by mid-May (Palmer, 1976). The rarity of eiders offshore in northern Baffin Bay in 1978 and 1979 
suggests that most cross Baffin Bay north of $76^{\circ} \mathrm{N}$ latitude, the northern edge of the regularly surveyed area. The king eiders observed migrating northwest along eastern Baffin Island may have, on the other hand, come from wintering areas along southwest Greenland, the east coast of North America, or both.

The decrease in numbers of both species of eiders around Coburg Island after the end of May may have been due to their direct departure for nesting areas. However, the concomitant increase in the Lancaster Sound area (Fig. 5) suggests that many birds moved south in order to travel through Lancaster Sound to the central Arctic. There was no increase in the numbers seen along eastern Baffin Island, and thus no indication that the birds in Lancaster Sound had newly arrived from the south. King eiders tend to arrive in large numbers in the Lancaster Sound area 1-2 wk earlier than common eiders and many king eiders have already departed, presumably for nesting areas, before peak numbers of common eiders arrive. King eiders arrive at nesting areas on northern Devon Island about a week earlier than common eiders (Hussell and Holroyd, 1974).

Most male eiders abandon the females soon after incubation begins (Salomonsen, 1968; Bellrose, 1976; Palmer, 1976). Most male king eiders that nest in the eastern and central parts of the Canadian Arctic Archipelago migrate to west Greenland to molt (Salomonsen, 1968, 1979); molt migrations of common eiders are less well known. Our data suggest that most eiders leaving nesting areas in central and east-central parts of the archipelago do so by way of Lancaster Sound, particularly along the south shore, and the east coasts of Bylot and Baffin islands. Densities in these areas were considerably higher than elsewhere in the study area in late July and early August. Male king eiders from more southern areas apparently fly east across Baffin Island (Wynne-Edwards, 1952).

The chronology of eastward migration was similar in 1976 and 1978. King eider males began to move out slightly earlier in July than common eider males and had essentially vanished by 15 August. Common eider males were also gone by 15 August. Many female eiders, presumably of both species, passed through Lancaster Sound in midAugust. Some of these birds likely had come from areas in the central arctic where peak numbers of female eiders along coasts occur in the first 10 days of August (M. McLaren, pers. obs.). Other workers have also reported large numbers of eiders moving through Lancaster Sound in August. For example, Duvall and Handley (1946) noted at least 10000 female eiders moving east along the north coast of Baffin Island on 27 August 1946.

At least small numbers of eiders molt in the eastern Lancaster Sound-northwest Baffin Bay area. Tuck and Lemieux (1959) reported over 10000 possibly molting king eiders in a bay west of Cape Hay, Bylot Island, in mid-July 1957. No molting birds were seen there in 1976 or 1978 , although they were seen elsewhere in our study area in these years.
We have no direct information about nesting success but the lower number of brood sightings in 1978 than in 1976 (when a much smaller area was surveyed) suggests that success was probably low in 1978. Most eiders seen during the last two surveys in 1978, from 30 September10 October, were in groups that did not flush. Most were in small areas of open water in the middle of rapidly forming coastal ice. Although these are late dates for young to be still flightless (cf. Bellrose, 1976), it is possible that these flocks were late broods.

\section{Effect of Ice Cover on Distribution}

Because oldsquaws and both eider species are benthic feeders (Ellarson, 1956; Palmer, 1976), their distribution in spring is likely determined by accessibility to shallow feeding areas. Oldsquaws may dive as deep as $60 \mathrm{~m}$ but eiders are restricted to more shallow water (Palmer, 1976). In 1976 and 1979 the shallow coastal waters of south Devon Island and north Bylot Island were ice-free during the spring migration period whereas in 1978 these waters were covered by extensive shelves of fast ice that persisted through July. In apparent response to these differing conditions, densities of oldsquaws in June were very high in the Coburg Island area but low in Lancaster Sound in 1978 and the reverse in 1979 (Fig. 2). In 1978 densities of eiders remained high near Coburg Island until the end of June, and numbers in Lancaster Sound never reached the peak numbers that occurred in 1976 and 1979 (Figs. 4,5). It is likely that the presence of large numbers of all three duck species near Coburg Island in late June 1978 was a result of displacement to one of the few shallow, ice-free parts of the study area. Lancaster Sound is probably a preferred feeding area. Thomson (1982) found the biomass $\left(\mathrm{g} \mathrm{m}^{-2}\right)$ of benthic fauna to be considerably higher in shallow waters of Lancaster Sound than at comparable depths in western Baffin Bay.

\section{APPENDIX}

OTHER WATERFOWL

\section{Canada Goose}

Three Canada geese were seen along the south side of Lancaster Sound between 31 May and 7 June 1976. One was seen along the south coast of Devon Island on 19 June 1979. None were seen in 1978.

\section{Brant}

Small numbers of brant were seen during each year of study. In 1976, about 412 were seen between 1 June and 5 September. Several flocks totalling at least 150 individuals were seen flying over Lancaster Sound about $10 \mathrm{~km}$ north of Bylot Island on 1 June. The remaining brant were along coasts or coastal ice-edges; all but seven were along south Devon Island. Included in the total was a flock of 25 
molting brant seen on 5 July 1976 . This is the only observation of molting brant in the three years.

In 1978, 247 brant were seen between 8 June and 9 September. The majority were along the shores of Lancaster Sound but small numbers occurred from Coburg Island south to Scott Inlet.

In 1979, 273 brant were seen between 10 and 30 June. They were scattered through the study area but most (179) were seen on 10 June along the fast ice edge across the mouth of Jones Sound.

\section{Snow Goose}

Snow geese nest at various locations throughout the study area but the largest colony (at least 20000 birds) is on southwest Bylot Island (H. Boyd in C.W.S., 1972). During all three years of study snow geese were seen exclusively along coasts and, in many cases, were on land beyond the transect strip.

We recorded a total of 1806 snow geese during surveys of eastern Lancaster Sound between 6 June and 7 September 1976. Most (1033) were in Croker Bay. Only four flocks ( 275 birds) of molting snow geese were seen, all off-transect on ponds. Brood flocks were seen at various locations but most ( 7 of 11 flocks - 73 of 112 young) were in Navy Board Inlet or along northwest Bylot Island. Areas near the large colony on southwest Bylot Island were not surveyed in 1976.

Most of the 6926 snow geese seen in 1978 were along southwest Bylot Island near the nesting colony. Only five were seen elsewhere in spring but larger numbers were seen in late summer. A flock of 500 was seen along southeast Devon Island on 22 August, and we saw 75 including 30 flying young there on 29 August. Small flocks of snow geese were seen flying south along the east coast of Baffin Island as late as 12 September. The snow geese seen along southwest Bylot Island through mid-August were primarily off-transect on the coastal lowlands. After mid-August adults and young moved to the waters of Navy Board Inlet and Eclipse Sound. The average brood size in 70 broods (including only groups with one or two adults) was $2.8 \pm$ SD 1.4 young.

In 1979 only 26 snow geese were seen at scattered locations between Coburg Island and the southwest coast of Devon Island. The 1979 observations included one blue goose.

\section{ACKNOWLEDGEMENTS}

This study was funded by Norlands Petroleums Ltd. in 1976 and by Petro-Canada Exploration, Inc. (as part of the Eastern Arctic Marine Environmental Studies) in 1978 and 1979. We thank Dr. A.T.C. Rutgers of Norlands and G.T. Glazier and H. Hume of Petro-Canada for their assistance. Logistic support was provided by Dr. Rutgers and by G. Koenig and S. Mackenzie of Petro-Canada. We especially thank the pilots of Petro-Canada and of Kenn Borek Air Ltd., who capably flew the surveys. The field work was conducted by the senior author and by W.E.
Renaud, W.R. Koski, S.R. Johnson, W.G. Johnston, R.E. Salter, M.A. Gollop, L.A. Patterson, P.D. Hollingdale, K.J. Finley, and J. Field of LGL Ltd. R.A. Davis and W.J. Richardson of LGL Ltd. provided assistance and guidance in planning and data analysis. W.J. Richardson, C. Holdsworth, B. DeLong and B. Griffen of LGL Ltd. helped in many ways in preparation of the manuscript.

\section{REFERENCES}

ALISON, R.M. 1975. Breeding biology and behavior of the oldsquaw (Clangula hyemalis L.). Ornithological Monographs 18:1-52.

BELLROSE, F.C. 1976. Ducks, Geese and Swans of North America. Harrisburg, PA: Stackpole Books. 544 p.

C.W.S. (Canadian Wildlife Service). 1972. Arctic ecology map series, descriptive reports. 2nd ed. Information Canada, Ottawa. 324 p.

DUVALL, A.J. and HANDLEY, C.O. 1946. Report of a wildlife reconnaissance of the eastern Canadian Arctic. Special Report, United States Department of the Interior, Fish and Wildlife Service, manuscript report. $138 \mathrm{p}$.

ELLARSON, R.S. 1956. A study of the oldsquaw duck on Lake Michigan. Unpubl. Ph.D. thesis, Univ. of Wisconsin, Madison, WI. 231 p.

ELLIS, D.V. 1956. Observations on the migration, distribution and breeding of birds in the Canadian Arctic during 1954 and 1955. Dansk Ornithologisk Forenings Tidsskrift 50:207-230.

GODFREY, W.E. 1966. The birds of Canada. National Museum of Canada Bulletin No. 203. 428 p.

GUNN, W.W.H. 1949. Report on wildlife observations, arctic weather station re-supply mission, July 15 to September 7, 1949. MS Rep. to Dominion Wildlife Service. Canada Dept. of Mines and Resources, Ottawa. 58 p.

HøRRING, R. 1937. Birds collected on the Fifth Thule expedition. In: Report of the Fifth Thule expedition, 1921-1924. Part 2: Zoology. Copenhagen. $133 \mathrm{p}$.

HUSSELL, D.J.T. and HOLROYD, G.L. 1974. Birds of the Truelove Lowland and adjacent areas of northeastern Devon Island, N.W.T. Canadian Field-Naturalist. 88:197-212.

JOHNSON, S.R. and RICHARDSON, W.J. 1981. Beaufort Sea barrier island-lagoon ecological process studies: Final report, Simpson Lagoon. Part 3. Birds. Environmental Assessment of the Alaskan Continental Shelf. Final Reports of Principal Investigators. Vol. 7. Biological Studies. National Oceanic and Atmospheric Administration, Boulder, CO. 275 p.

McLAREN, P.L. 1982. Spring migration and habitat use by seabirds in eastern Lancaster Sound and western Baffin Bay. Arctic 35 (this issue).

PALMER, R.S. [ed.]. 1976. Handbook of North American Birds. Vol. 3. Waterfowl. New Haven and London: Yale University Press. $560 \mathrm{p}$.

RENAUD, W.E. and McLAREN, P.L. 1982. Ivory gull (Pagophila eburnea) distribution in late summer and autumn in eastern Lancaster Sound and western Baffin Bay. Arctic 35 (this issue).

RENAUD, W.E., JOHNSTON, W.G. and FINLEY, K.J. 1981. The avifauna of the Pond Inlet region, N.W.T. American Birds 35:119-129.

SALOMONSEN, F. 1950. The Birds of Greenland. Copenhagen: Munksgaard. $608 \mathrm{p}$.

1968. The moult migration. Wildfowl 19:5-24.

1979. [Thirteenth preliminary list of recoveries abroad of birds ringed in Greenland.] Dansk Ornithologisk Forenings Tidsskrift 73:191-206 (English summary).

THOMSON, D.H. 1982. Marine benthos in the eastern Canadian High Arctic: multivariate analyses of standing crop and community structure. Arctic 35 (this issue).

TUCK, L.M. and LEMIEUX, L. 1959. The avifauna of Bylot Island. Dansk Ornithologisk Forenings Tidsskrift 53:137-154.

WYNNE-EDWARDS, V.C. 1952. Zoology of the Baird Expedition (1950). I. The birds observed in central and southeast Baffin Island. Auk 69:353-381. 